\title{
Resistance of Multipotent Mesenchymal Stromal Cells to Anoxia In Vitro
}

\author{
L.B. Buravkova, E.R. Andreeva, J.V. Rylova and A.I. Grigoriev \\ Institute of Biomedical Problems, Russian Academy of Sciences, \\ Faculty of Basic Medicine MSU, Moscow, \\ Russia
}

\section{Introduction}

Oxygen balance is a corner element of tissue physiology. The damaging effects of oxygen deprivation have been under consideration over at least 100 years. Recently, interest to hypoxia and practically complete absence of oxygen referred to as anoxia has been rekindled in context of the great progress made in the studies of stem/progenitor cell function in organism. The hallmark of stem cells is ability to self-renew and maintain multipotency. This ability depends on the balance of complex signals in their microenvironment. One of the most important findings is that oxygen represents a crucial component determining stem cells homeostasis within their native tissue niche. The stem cell niche has come to refer to a defined anatomical compartment that includes cellular and acellular components that integrate both systemic and local cues to regulate the stem cells biology [Jones and Wagers, 2008; Li and Xie, 2005; Scadden, 2006; Yin and Li, 2006; Buravkova \& Andreeva, 2010]. The first specialized tissue niche was described for hematopoietic cells in bone marrow [Schofield, 1978]. Cells, blood vessels, matrix glycoproteins, and the three-dimensional space formed the architecture of a highly specialized microenvironment for stem cells [Scadden, 2006]. Oxygen measurements in tissues known to harbor stem cells revealed low level of oxygen, and raised the question of whether such an environment was necessary for the niche to maintain stem cells [Braun et al., 2001; Cipolleschi et al., 1993; Erecinska and Silver, 2001]. Recent evidence has broadened the spectrum of stem cells influenced by limited oxygen supply including cancer stem cells and induced pluripotent stem cells [Brahimi-Horn \& Pouysse'gur, 2007]. Low oxygen tension maintains the undifferentiated state of embryonic, hematopoietic, mesenchymal, and neural stem cell phenotypes, and affects proliferation and cell-fate commitment [Mohyeldin et al., 2010].

Multipotent mesenchymal stem/stromal cells (MMSCs) arouse interest of cell biologists because of high proliferating activity and multilineage differentiion capacity. These cells are also shown to be immunoprivilege and to possess immunosuppressive features. The MMSC properties taken together make these cells a very attractive tool for cell therapy and regenerative medicine. By and large, manifestation of the MMSC properties is strictly dependent on oxygen concentration in native milieu. Moreover, the best realization of the regenerative potential is closely associated with low or very low oxygen level in the area of tissue damage. 
The chapter highlights the recent progress in evaluation of the pivotal role of low oxygen in MMSC milieu and how it uniquely modulates the MMSC properties.

\section{MMSCs and microenvironmental requirements: the role of oxygen}

MMSCs (a rare population of non-hematopoietic stem/progenitor cells) are the subject of increasing scientific interest due to the key role they play in physiological renewal and repair. For a long time there was only one special tissue known as a definite source for renewal and substitution of cells in mammals, humans in particular. It was bone marrow capable to produce new mature blood cells from undifferentiated hematopoietic precursors. Marrow stroma contains many cell elements including endothelial cells of vessels, reticular cells, fibroblasts, adipocytes, stromal cells, and macrophages. Among the multiple stromal cells there is a minor population of MMSCs that localizes assumingly in perivascular regions of the bone marrow [Fridenshtein et al., 1976]. According to the modern concept, this population has the capacity to differentiate into cells of mesenchymal lineage (osteoblasts, chondroblasts, adipocytes and some other types of cells) [Kolf et al., 2007; Losito et al., 2009; Mohyeldin et al., 2010].

The direct evidence of stromal progenitor cells entity in vivo was not available due to the lack of a single definitive marker; therefore, demonstration of their existence has relied primarily on retrospective in vitro assays. To date, identification and characterization of bone marrow MMSCs from various animal species and humans have been described in numerous papers. It was recognized that the main phenotypic MMSC features should satisfy the following three basic criteria: adhesion to plastic, extended self-maintenance in culture, and the capacity to differentiate into bone, cartilage, adipose and hematopoiesisinducing stroma during transplantation in vivo or upon certain inductive stimuli in vitro [Caplan, 2007; Kolf et al., 2007].

As it has been already mentioned, firstly MMSCs were described in bone marrow. Subsequently cells with characteristics similar to MMSCs were isolated from other tissue sources, including trabecular bone, adipose tissue, synovium, skeletal muscle, lung, deciduous teeth, and human umbilical cord perivascular cells derived from the Wharton's Jelly, peripheral blood, dental pulp, periodontal ligament and etc. (Tabl. 1) [for refs. see also Kolf et al., 2007; Augello et al., 2010].

These findings reveal that MMSCs are diversely distributed in vivo and, as a result, may occupy a ubiquitous stem cell niche. There is a hypothesis that these cells are the common source of multipotent cells in adult organism migrating constantly in various mesenchymal tissues and providing their maintenance, renewal and regeneration.

The stem/progenitor cell microenvironment constists of specific molecular, cellular, and physiological components and is subject to physical and mechanical stimuli. Although stem cells can reside in markedly different locations and have distinctly different developmental paths, low oxygen tension (termed hypoxia or, in case of extremely low $\mathrm{O}_{2}$, anoxia) seems to be a common in vivo feature shared by many types of adult stem cells. Indeed, there is increasing evidence that presence/absence of oxygen is a powerful tool that regulates stem cell proliferation and differentiation [Ma et al., 2009]. 


\begin{tabular}{|l|l|}
\hline Tissue source & Representative References \\
\hline \multirow{3}{*}{ Bone marrow } & $\begin{array}{l}\text { Bruder et al., 1998; Pittenger et al., 1999; Makino et al., 1999; } \\
\text { Majumdar et al., 2000; Bianco et al., 2001; Shake et al., 2002; Shi } \\
\text { \& Grontos, 2003; Lee et al., 2004; Wagner et al., 2005; Romanov } \\
\text { et al., 2006; Fehrer et al., 2007 }\end{array}$ \\
\hline Adipose tissue & $\begin{array}{l}\text { Zuk et al., 2001, 2002; Lee et al., 2004; Rehman et al., 2004; } \\
\text { Wagner et al., 2005; Romanov et al., 2006; Gimble et al., 2007; } \\
\text { Schaffler et al., 2007; Buravkova et al., 2009; Madonna et al., } \\
2009\end{array}$ \\
\hline Muscle & Bosch et al., 2000; Black, 2001 \\
\hline Umbilical cord blood & Wagner et al., 2005; Caballero et al., 2010 \\
\hline Peripheral blood & Zvaifler et al., 2000 \\
\hline Dermis & Black, 2001 \\
\hline Periosteum & Caballero et al., 2010 \\
\hline Dental pulp & Shi \& Grontos, 2003 \\
\hline Synovial membrane & Kurose et al., 2010 \\
\hline
\end{tabular}

Table 1. MMSC tissue sources in humans.

The role of oxygen in maintaining of both self-renewal and committed status of hematopoietic cells has been described in detail [Ivanovic, 2009; Eliasson \& Jonasson, 2010, Valtieri \& Sorrenino, 2008]. In bone marrow, the hematopoietic compartments are bound by stromal elements [Kolf et al., 2007], mainly MMSCs, and such way that two cell types form an integral part of each other's niche. Although the importance of understanding the progenitor cell spatial distribution with respect to oxygen supply from blood vessel has long been recognized, a direct noninvasive in vivo measurement of spatial oxygen gradient in bone marrow has been a major technical hurdle. Early direct measurements revealed that bone marrow is generally hypoxic with $\mathrm{O}_{2}$ in some regions as low as $\sim 1-2 \%$ [Cipolleschi et al., 1993] and even close to anoxia $0.1 \% \mathrm{O}_{2}$ in the osteoblastic niche [Calvi et al., 2003]. Results from the recent in vivo studies provided a direct experimental evidence that longterm repopulating HSCs in mouse reside in hypoxic environment [Parmar et al., 2007] and that hypoxia may in fact be an essential part of microenvironment maintaining cells in the undifferentiated state. On the other hand, hypoxia increases erythropoiesis - one of hematopoietic lineage, - by EPO or, maybe, low $\mathrm{O}_{2}$ [Vlaski et al., 2009].

Based on these data, one may assume that MMSC physiology as an integral part of HSCs niche is also governed mainly by hypoxic and even anoxic conditions. Unlike HSCs residing exactly in bone marrow, MMSCs localize in other perivascular tissue depots and, being involved in regenerative and reparative processes are faced with different oxygen conditions; therefore, they should possess a high degree of $\mathrm{O}_{2}$-mediated plasticity. Low/extremely low (hypoxia/anoxia) oxygen partial pressure in extracellular space may be physiologic or damaging in consequence of insufficient blood supply to impaired tissue. Low oxygen can modify drastically morphologic and functional cell properties, such as viability, proliferative status, immunophenotype, and differentiation. On the other hand, it is known that different cells have different tolerance to low oxygen [Csete, 2005; Ivanovic, 2009]. MMSCs, a mixture of stem/progenitor cells that may come to be in different oxygen milieu in vivo, are an attractive experimental model to explore the intrinsic mechanisms of cell adaptation to oxygen limitation. 
The major bulk of knowledge concerning mesenchymal stem/progenitors biology came from the in vitro studies. The high proliferative activity underlies the MMSC ability to selfrenew in culture for an extended period without a dramatic decline of the telomerase activity and change of karyotype [Bruder et al., 1997; Izadpanah et al., 2006], and to form an uniform layer of adhesive spindle-shaped cells with typical fibroblast-like morphology in vitro in the normalized conditions, i.e. low glucose content, absence of differentiation stimuli and appropriate seeding density [Pittenger et al., 1999]. The composition of the gaseous phase in cell culture technique is the most conservative parameter and exploring atmospheric $\mathrm{O}_{2}$ concentration. It should be taken into account that oxygen concentration is significantly lower in vivo. Arterial blood contains about $12 \%$ oxygen, and the mean tissue level of oxygen is about $3 \%$ with considerable local and regional variation. These are values for adult organs and tissues. Mean oxygen tension in embryonic tissue (where stem cells are enriched relative to adult tissues) is considerably less. Although many papers refer to low oxygen levels in embryos as "hypoxic," they are actually "normoxic" for the time and place of development [Csete, 2005]. In the last decade it was demonstrated that low oxygen tension influences greatly biology of both embryonic and adult stem cell in vitro [Eliasson and Jonsson, 2010; Panchision, 2009; Silvan et al., 2009] improving the proliferative and migrating abilities and reducing differentiation and proapoptotic reaction of stem cells. These observations fueled a hypothesis that low oxygen tension could be critical, but not damaging to stem cells microenvironment.

Nowadays, in vitro studies of the oxygen effect on MMSC functional properties are growing in number. The initial theory that the replicating stem cell microenvironment should provide sufficient oxygen supply to support tissue growth evolved to the understanding of a more complex signaling role of oxygen in regulation of stem cells migration, differentiation, and development [Ma et al., 2009]. Despite the claim that low and extremely low $\mathrm{O}_{2}$ may be more representative of the physiological conditions for certain cell types than so-called "normoxia", low oxygen is traditionally called hypoxia in consistency with the conventional terminology.

At the moment, there is wealth of data concerning low oxygen effects on the functional properties of MMSCs in vitro. It was demonstrated clearly that hypoxia of different severity induces proliferation in cultured MMSCs from various species. Thus, an increased proliferation rate was demonstrated for rat bone marrow MMSCs at 5\% $\mathrm{O}_{2}$ [Lennon et al., 2001; Buravkova \& Anokhina, 2007,2008]. Also, proliferation of human bone marrow MMSCs was stimulated by $2 \% \mathrm{O}_{2}$ [Grayson et al., 2006], 3\% $0_{2}$ [Fehrer et al., 2007; D'Ippolito et al., 2006], and 5\% $\mathrm{O}_{2}$ [Zhambalova et al., 2010]. Accelerated cell growth was observed in pig bone marrow MMSC culture at 5\% $\mathrm{O}_{2}$ [Bosch et al, 2006] and murine's bone marrow MMSCs at $8 \% \mathrm{O}_{2}$ [Ren et al., 2006]. Villarruel S.M. and coauthors [2008] estimated the human bone marrow MMSC colony-forming potential at 1, 5, 10, and $20 \% \mathrm{O}_{2}$, and found that the number of CFU-F raised most at $5 \% \mathrm{O}_{2}$. The data on MMSCs under low oxygen pressure are also discussed in detail in several review papers [Malda et al., 2007; Ma et al., 2009; Das et al., 2010].

Under reduced oxygen pressure MMSCs also display angiogenic activity. At $1 \% \mathrm{O}_{2}$, murine's bone marrow MMSCs migrated rapidly, formed a three-dimensional capillary-like structure in Matrigel, and synthesized more vascular endothelial growth factor (VEGF); matrix metalloproteinase (MMP)-2 mRNA expression and protein secretion were down 
regulated, while those of membrane-type (MT)MMP-1 were strongly induced by hypoxia [Annabi et al., 2003]. The capillary-like structures were also demonstrated in hypoxic (5\%) cultures of human marrow MMSCs [Zhambalova et al., 2010] and adipose tissue MMSCs [Grinakovskaya, personal communication].

MMSCs are considered as a perspective tool for regenerative medicine and approaches to improve MMSCs quality are being developed rapidly. The preconditioning in low oxygen medium is one of the attractive ways. It was demonstrated that preconditioning of human marrow-derived MMSCs in 1\%-3\% oxygen activated the Akt-signaling pathway while maintaining cell viability and cell cycle rates, induced expression of cMet, the major receptor for hepatocyte growth factor (HGF), and enhanced cMet signaling. MMSCs cultured in hypoxic conditions increased migration rate. Preconditioned normoxic and hypoxic MMSCs equally improved revascularization after surgical hind limb ischemia; however, restoration of blood flow was observed significantly earlier in mice that had been injected with hypoxic preconditioned MMSCs [Rosova et al., 2008]. According to $\mathrm{Hu}$ et al. [2008], subletally hypoxic close to anoxia (0.5\%) preconditioning of murine bone marrow MMSCs increased expression of prosurvival and proangiogenic factors including hypoxia-inducible factor 1 , angiopoietin-1, vascular endothelial growth factor and its receptor, Flk-1, erythropoietin, $\mathrm{Bcl}-2$, and Bcl-xL. Caspase-3 activation in hypoxic MMSCs and populaltion of apoptotic cells were significantly lower compared with normoxic cells in vitro. Transplantation of hypoxic vs normoxic MMSCs after myocardial infarction resulted in an increase in angiogenesis, as well as enhanced morphologic and functional benefits of stem cell therapy [Hu et al., 2008].

The adipose tissue-derived MMSCs under low oxygen pressure are of special interest because of the considerable promise for regenerative medicine and cell therapy. Most of the data on MMSCs at low $\mathrm{O}_{2}$ were gathered using bone marrow MMSCs. Much less investigations have been concerned with the hypoxia effects on stromal cells derived from adipose tissue.

In a few papers hypoxia has been shown to affect the differentiation potential of the adipose tissue-derived MMCSs. Wang et al. [2005] demonstrated that human adipose MMSCs in alginate beads did not display proliferative activity at $5 \% \mathrm{O}_{2}$ in normal expansion medium; however in chondrogenic medium its growth rates was lower at $5 \%$ in comparison with $20 \% \mathrm{O}_{2}$. Still, under these conditions they exhibited enhanced chondrogenic differentiation markers including collagen II, glucosaminoglycan, and chondroitin-4-sulfate production [Wang et al., 2005]. The hypoxia effect on adipose tissue MMSCs is strongly dependent on the cultivation conditions. For this reason, there are conflicting data regarding chondrogenic gene expression during induction under hypoxic conditions [Khan et al., 2007; Betre et al., 2006]. Adipose tissue MMSCs expanded in $20 \% \mathrm{O}_{2}$ and transferred into a $2 \% \mathrm{O}_{2}$ environment failed to differentiate robustly to either adipogenic or osteogenic lineages as compared with adipose MMSCs differentiated in normal atmospheric conditions [Lee \& Kemp, 2006].

We have developed an experimental approach utilizing permanent expansion of adipose tissue derived MMSCs at a reduced oxygen tension [Buravkova et al., 2009]. In hypoxia (5\% $\mathrm{O}_{2}$ ) MMSCs demonstrated enhanced growth exceeding that in normoxia $\left(20 \% \mathrm{O}_{2}\right)$ in $2.9 \pm 0.2$ folds ( $\mathrm{p}<0.05)$ [Buravkova et al., 2009]. The osteogenic differentiation capacity of MMSCs was significantly reduced in hypoxia vs normoxia [Grinakovskaya et al., 2009]. 
After expansion at low oxygen (2\%) adipose tissue derived MMSCs were able to enhance the wound-healing function. Conditioning medium of hypoxic MMSCs promoted significantly collagen synthesis and migration of human dermal fibroblasts in vitro, and reduced the wound area in animal studies. These effects were based on up-regulation of growth factors such as the vascular endothelial growth factor (VEGF) and basic fibroblast growth factor (bFGF) [Lee et al., 2009].

The data above demonstrated clearly that low oxygen concentration in MMSCs microenvironment in vitro leads to modulation of MMSCs functions rather than impairment. The question arises whether extremely low oxygen $\left(\sim 0 \% \mathrm{O}_{2}\right)$ brings damage to MMSCs?

Papers dedicated to MMSCs and anoxia are few and far between. Nevertheless, the data on the "true" anoxia effects on MMSCs in vitro do exist. For example, studies of Annexin Vpositive cells in rat bone marrow MMSC culture during $12 \mathrm{~h}$ anoxia exposure revealed a time-dependent increase in apoptotic cells from 3\% to 15\%. When following a $3 \mathrm{~h}$ anoxic exposure these MMSCs (apoptotic rate $\sim 4 \%$ ) were cocultured with rat's cardiomyocytes or injected into infarcted zone in the heart, cardiomyocyte death reduced significantly owing to the treatmeant with both normoxic MMSCs and anoxic MMSCs, the Bcl-2/Bax protein ratio increased and cleaved cysteine-aspartic acid protease-3 decreased; anoxic MMSCs were superior to MMSCs in the normoxic condition. Consequently, MMSCs exert the antiapoptotic effect on cardiomyocytes, partially by paracrine action. The authors assume that anoxic preconditioning may be an effective and convenient way to enhance the cardioprotective effect of MMSCs [He et al., 2009].

\section{Resistance of rat's marrow MMSCs to extremely low oxygen}

Cell morphology and immunophenotype. We have examined the direct effects of $96 \mathrm{~h}$ anoxia $\left(\sim 0 \% \mathrm{O}_{2}\right)$ on rat bone marrow MMSCs. Anoxia did not affect cell morphology. The percentage of MMSCs bearing CD90, CD54, CD44, CD29 (more than 95\%), CD45, CD11b (less than $0.6 \%$ ) molecules, and pattern of molecules expression were identical in normoxic and anoxic cells. The slight reduction in percentage of positive cells at anoxia was observed only for the CD73 marker (72\% in normoxia vs $67 \%$ in anoxia).

Cell growth. Assessment of bone marrow MMSC proliferation in 1-4th passages did not reveal inhibition of the MMSC proliferative activity [Fig. 1; Anokhina et al., 2009]. It should be mentioned that during MMSC exposure in hypoxia proliferative rate displayed a more pronounced excess over normoxic MMSCs [Buravkova et al., 2007] as compared to anoxic MMSCs. Nevertheless, the fact that MMSCs can really proliferate in anoxia seems amazing and deserves special attention.

Absence of evidence for cell proliferation inhibition/deceleration in anoxia disagrees with the results of experiments demonstrating the cell cycle arrest in the conditions of anoxia [Amellem et al., 1994; Gardner et al., 2001; Goda et al., 2003].

The mechanism of inactivation of enzymes involved in nucleic acids production and subsequent inhibition of DNA replication was proposed as an explanation of the phenomenon of the cell growth arrest in murine embryonic fibroblasts and splenic B lymphocytes in low oxygen environment. Moreover, this held true for total oxygen deprivation $(0.01 \%)$ or anoxia only, but not for $0.1-1 \% \mathrm{O}_{2}$ [Goda et al., 2003]. The drop in 
bromodeoxyuridine incorporation into murine embryonic fibroblast DNA also confirmed growth arrest due to blockade of replication in anoxia [Gardner et al., 2001]. At very low $\mathrm{O}_{2}$ (0.01-0.13\%) NHIK 3025 cells were able to enter into S-phase of cell cycle but failed to complete DNA synthesis [Amellem et al., 1994].

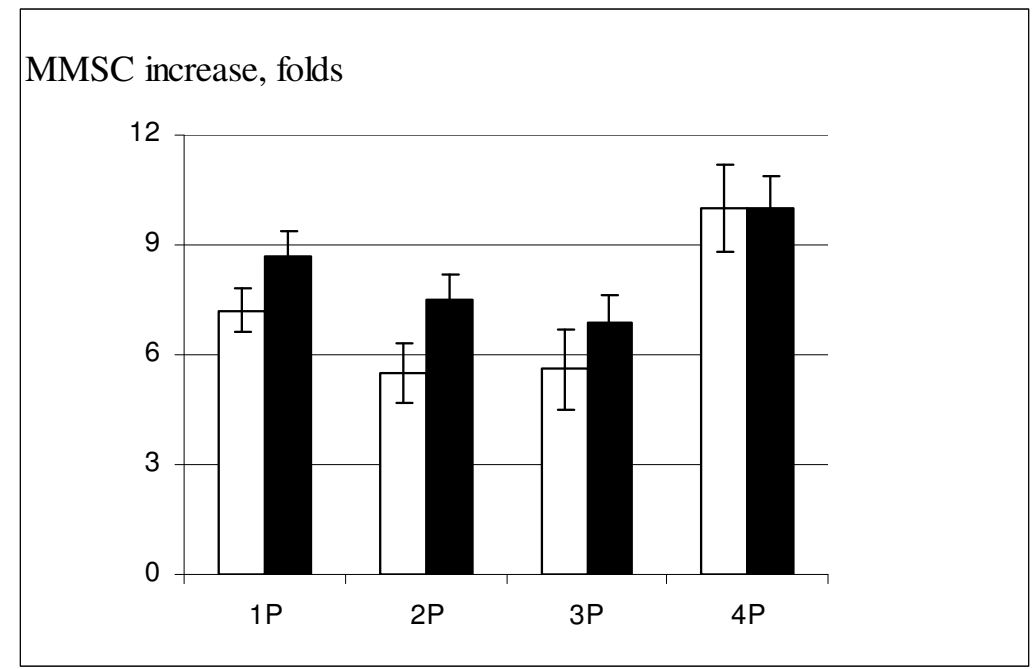

Fig. 1. Rat bone marrow MMSC growth after $96 \mathrm{~h}$ of exposure in $20 \% \mathrm{O}_{2}-\square$, and $\sim 0 \% \mathrm{O}_{2}-$ on $1^{\text {st }}-4^{\text {th }}$ passages. The averaged data of 7 independent experiments are presented as $\mathrm{M}+\mathrm{m}$.

However, in anoxic conditions MMSCs showed a normal process of cell division. It is known that different cell types are characterized by varying resistance to $\mathrm{O}_{2}$ deprivation in microenvironment [Ivanovic, 2009; Mohyeldin et al., 2010]. If a trace amount of $\mathrm{O}_{2}$ remaining in pericellular space after gas force-out is sufficient for DNA replication, cell division can be completed successfully, otherwise cells will undergo apoptosis. On the other hand, it was shown that fibroblasts are able to recover after the cell cycle arrest in anoxic conditions [Gardner et al., 2001]. To sum up, cellular mechanisms underlying MMSCs proliferation in anoxia are not clear.

Cell viability. The data on MMSCs viability in normoxic vs anoxic conditions are presented on Fig. 2. Though the share of damaged (apoptotic+necrotic) cells in anoxia did not differ from that in normoxic conditions significantly, the rate of apoptotic cells was doubled in anoxia $(\mathrm{p}<0.05)$ (Fig. 2).

Therefore, $96 \mathrm{~h}$ anoxia did not lead to a considerable increase in the number of damaged cells. At the same time, anoxia appeared to induce apoptosis in MMSCs. It is believed that apoptosis may be associated with anoxia, since a significant $\mathrm{O}_{2}$ reduction increases frequency of point mutations accumulation of which can be prevented by cell death through the apoptotic path [Greijer \& van der Wall, 2004]. Apoptosis due to $\mathrm{O}_{2}$ deprivation can be triggered by different mechanisms. The key role is played by ROS, JNK kinase, and cytochrome $\mathrm{C}$ release from mitochondria mediated, in its turn, by various factors including 
p53. p53 induction may result from stabilization of HIF-1a protein, the key transcription factor involved in hypoxia and capable to start other, p53-indepent mechanisms of apoptosis [Greijer \& van der Wall, 2004]. Besides apoptosis, $\mathrm{O}_{2}$ deprivation can mobilize some other cell death pathways based on indirect effects of $\mathrm{O}_{2}$ reduction. Intracellular acidosis triggered by $\mathrm{O}_{2}$ deprivation is the most important one [Schmaltz et al., 1998].

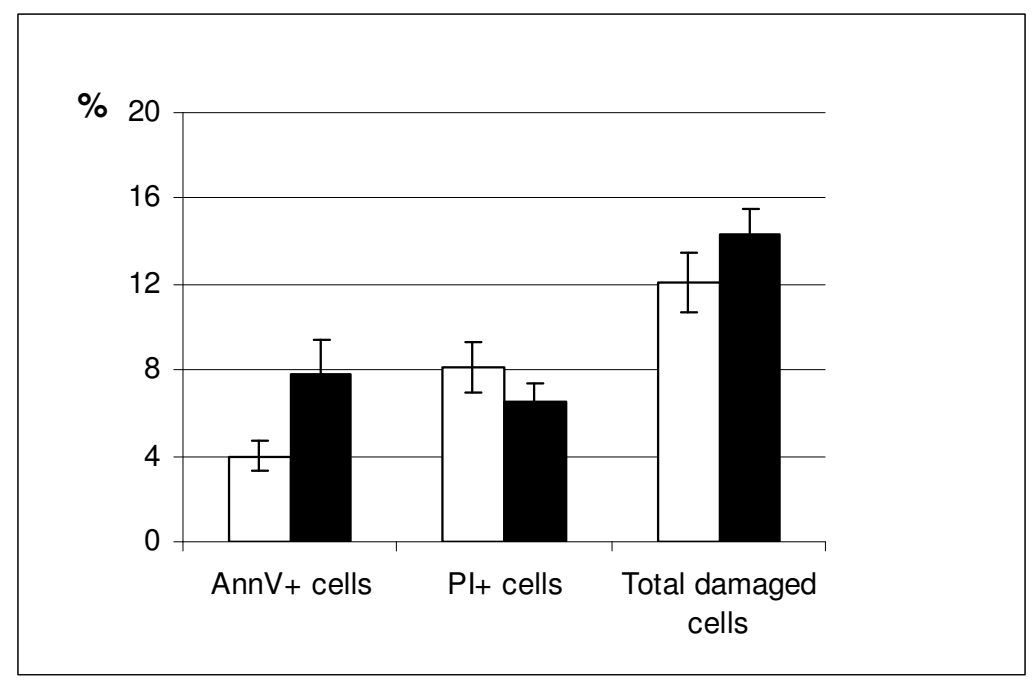

Fig. 2. Rat bone marrow MMSC viability after $96 \mathrm{~h}$ of exposure in $20 \% \mathrm{O}_{2}-\square$, and $\sim 0 \% \mathrm{O}_{2}-$. AnnV+ cells - MMSCs, stained with Annexin V-FITC. PI+ cells - MMSCs stained with Propidium Iodide. Total damaged cells $-($ AnnV + cells $)+(P I+$ cells $)$. The averaged data of 12 independent experiments are presented as $\mathrm{M} \pm \mathrm{m}$.

Earlier we described the antiapoptotic effects of hypoxia on rat bone marrow MMSCs [Buravkova et al., 2007]. The antiapoptotic effect of hypoxia and proapoptotic effect of anoxia may be explained using the data on the impact of HIF phosphorylation level on cell viability. The dephosphorylated HIF-1a subunit may indicate the proapoptotic HIF effect through p53 binding, whereas phosphorylated HIF-1a does not [Suzukiet al., 2001]. It may also come in line with the data suggesting that the proapoptotic effect of low oxygen depends on HIF stabilization occurring mostly at less than $5 \%$ oxygen, while the antiapoptotic hypoxia effect takes place regardless of HIF [Jiang, Semenza, Bauer 1996; Greijer \& van der Wall, 2004].

Thus, path of cell death may be determined by severity of $\mathrm{O}_{2}$ deprivation which is illustrated by the opposing apoptotic trends in hypoxia and anoxia.

Despite the relative MMSC resistance to $96 \mathrm{~h}$ anoxia, a prolonged exposure (up to 3 weeks) to anoxic conditions resulted in a significant reduction in cells viability (Tabl. 2). During 3 weeks in culture the percent of damaged MMSCs in normoxia and hypoxia varied insignificantly (Tabl. 2). Prolonged MMSCs exposure in anoxia led to a drastic decrease in viability up to $22 \%$ after one week, $50 \%$ after 2 weeks and to practically total cell death after 
3 weeks. Necrosis was the predominant path of cell death in anoxic MMSCs, though the percentage of apoptotic cells increased also significantly (Tab.2).

\begin{tabular}{|c|c|c|c|}
\hline After $1^{\text {st }}$ week & AnnV+ $(\%)$ & $P I+(\%)$ & Damaged cells, total $(\%)$ \\
\hline Normoxia $\left(20 \% \mathrm{O}_{2}\right)$ & $5,7 \pm 0,7$ & $5,0 \pm 0,2$ & $10,8 \pm 0,9$ \\
\hline Hypoxia $\left(5 \% \mathrm{O}_{2}\right)$ & $4,9 \pm 0,8$ & $10,0 \pm 0,7$ & $14,9 \pm 0,1$ \\
\hline Anoxia $\left(\sim 0 \% \mathrm{O}_{2}\right)$ & $8,1 \pm 0,7$ & $13,9 \pm 0,6$ & 22,0 \\
\hline After 2 weeks & & & $6,2 \pm 0,2$ \\
\hline Normoxia $\left(20 \% \mathrm{O}_{2}\right)$ & $1,2 \pm 0,2$ & $4,9 \pm 0,04$ & $13,3 \pm 0,5$ \\
\hline Hypoxia $\left(5 \% \mathrm{O}_{2}\right)$ & $3,0 \pm 0,01$ & $10,3 \pm 0,5$ & $58,9 \pm 1,6$ \\
\hline Anoxia $\left(\sim 0 \% \mathrm{O}_{2}\right)$ & $16,8 \pm 0,4$ & $42,2 \pm 2,0$ & $9,7 \pm 0,5$ \\
\hline After 3 weeks & & & $7,8 \pm 0,3$ \\
\hline Normoxia $\left(20 \% \mathrm{O}_{2}\right)$ & $1,4 \pm 0,4$ & $8,2 \pm 0,1$ & $97,2 \pm 1,1$ \\
\hline Hypoxia $\left(5 \% \mathrm{O}_{2}\right)$ & $0,4 \pm 0,1$ & $7,4 \pm 0,4$ & $8,0 \pm 0,7$ \\
\hline Anoxia $\left(\sim 0 \% \mathrm{O}_{2}\right)$ & $8,2 \pm 0,4$ & 89,0 & \\
\hline
\end{tabular}

The averaged data of 5 independent experiments are presented as $M \pm m$.

Table 2. Rat bone marrow MMSC viability after prolonged exposure in normoxia, hypoxia and anoxia.

The predominance of necrosis over apoptosis in MMSCs in the course of prolonged exposure to anoxia seems quite natural. In contrast to necrosis, apoptosis is a programmed energy-dependent cell death and, therefore, cell death path is determined by energy state of cells [Leist et al., 1997].

Consequently, MMSC death due to short-term anoxia is minimal and realized primary through the apoptotic pathway. Prolonged anoxic exposure induced massive cell death associated mainly with necrosis.

Cell differentiation. Evaluation of the MMSC differentiation capacity was carried out after 8 days in anoxia because of quite rapid decline of MMSC viability with exposure extention, as was described above. Spontaneous and induced osteogenic differentiation was revealed in anoxic MMSCs with alkaline phosphatase staining; the intensity of the process was found significantly less pronounced than in normoxic MMSCs (Fig.3). The mechanism of $\mathrm{O}_{2^{-}}$ mediated suppression of osteogenic capacity of human bone marrow MMSCs and murine osteoblasts in the condition of $\mathrm{O}_{2}$ deprivation (hypoxia $\left(2 \% \mathrm{O}_{2}\right)$ and anoxia $\left.\left(0.02 \% \mathrm{O}_{2}\right)\right)$ was demonstrated earlier. The authors made a supposition that anoxia rather than hypoxia provoked inhibition of Runx2 protein expression, the key transcription factor in osteogenesis. Runx2 suppression resulted in inhibition of nodule formation and a significant reduction in mineralization of the extracellular matrix [Salim et al., 2004]. 

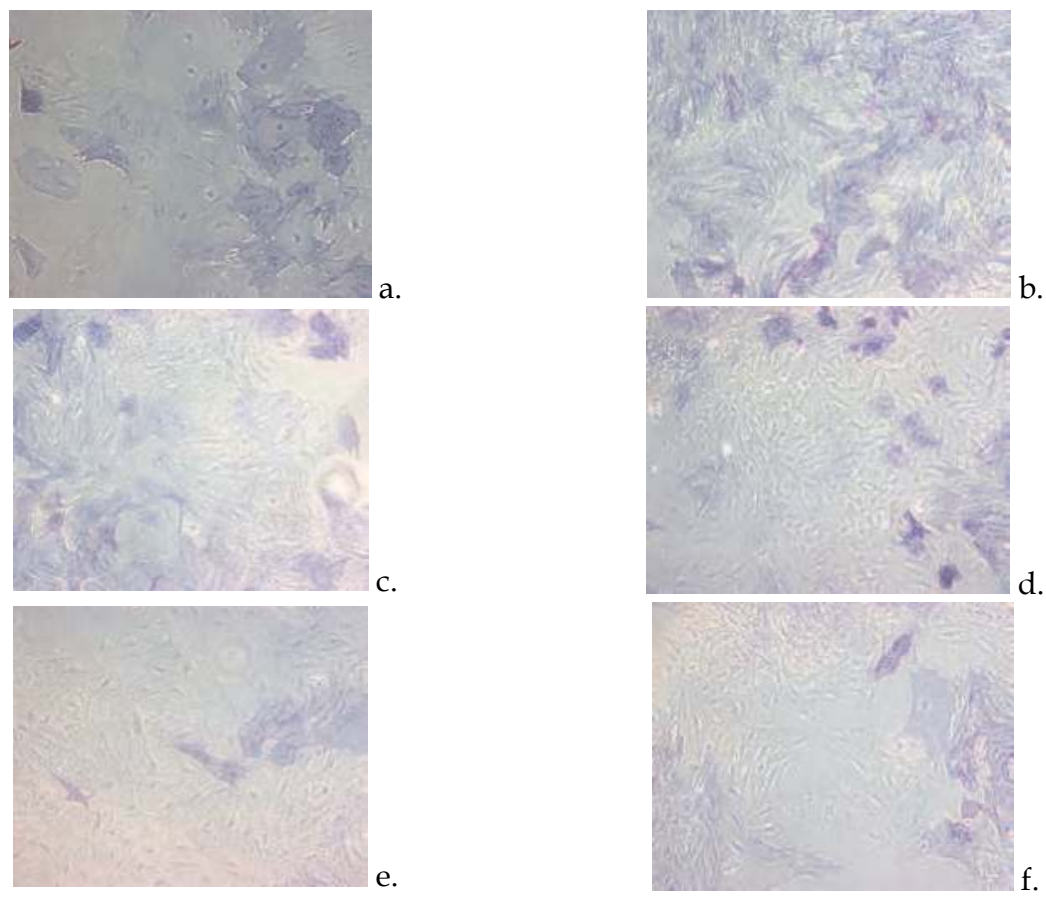

Fig. 3. Spontaneous $(\mathrm{a}, \mathrm{c}, \mathrm{e})$ and induced $(\mathrm{b}, \mathrm{d}, \mathrm{f})$ osteodifferentiation in rat bone marrow MMSCs after 8 days exposure in normoxic $\left(20 \% \mathrm{O}_{2}\right)(\mathrm{a}, \mathrm{b})$, hypoxic $\left(5 \% \mathrm{O}_{2}\right)(\mathrm{c}, \mathrm{d})$ and anoxic $\left(\sim 0 \% \mathrm{O}_{2}\right)(\mathrm{e}, \mathrm{f})$ conditions. Alkaline phosphatase, representative images of MMSCs on $3^{\text {rd }}$ passage, 100x.

Accumulation of lipid droplets in anoxic MMSCs indicated of differentiation in the adipogenic direction was both spontaneus and induced (Fig. 4). Further extension of exposure in anoxia caused death of differentiating MMSCs. It appears that alteration of MMSCs viability rather than of differentiating capacity was the cause of differentiation suppression in anoxia.

Thus, $96 \mathrm{~h}$ anoxia didn't lead to changes in MMSC morphology, proliferation rate and immunophenotype, which may obviously indicate MMSC functional stability under reduced oxygen tension. Also, anoxia didn't increase significantly the percentage of damaged cells despite some activation of apoptosis. Further MMSC propagation in anoxia led to progressive damage of cells mainly by necrosis in contrast to apoptosis as a main death pathway in short-term anoxia and the antiapoptotic effect of hypoxia. Short-term anoxia did not inhibit the initial stages of stimulated adipo- and osteo-differentiation [Tuncay et al., 1994; Matsuda et al., 1998]. Probably, trace oxygen is enough for some MMSCs to start differentiation and the only limiting factor is viability in anoxia rather than termination of the differentiation signaling pathways. 

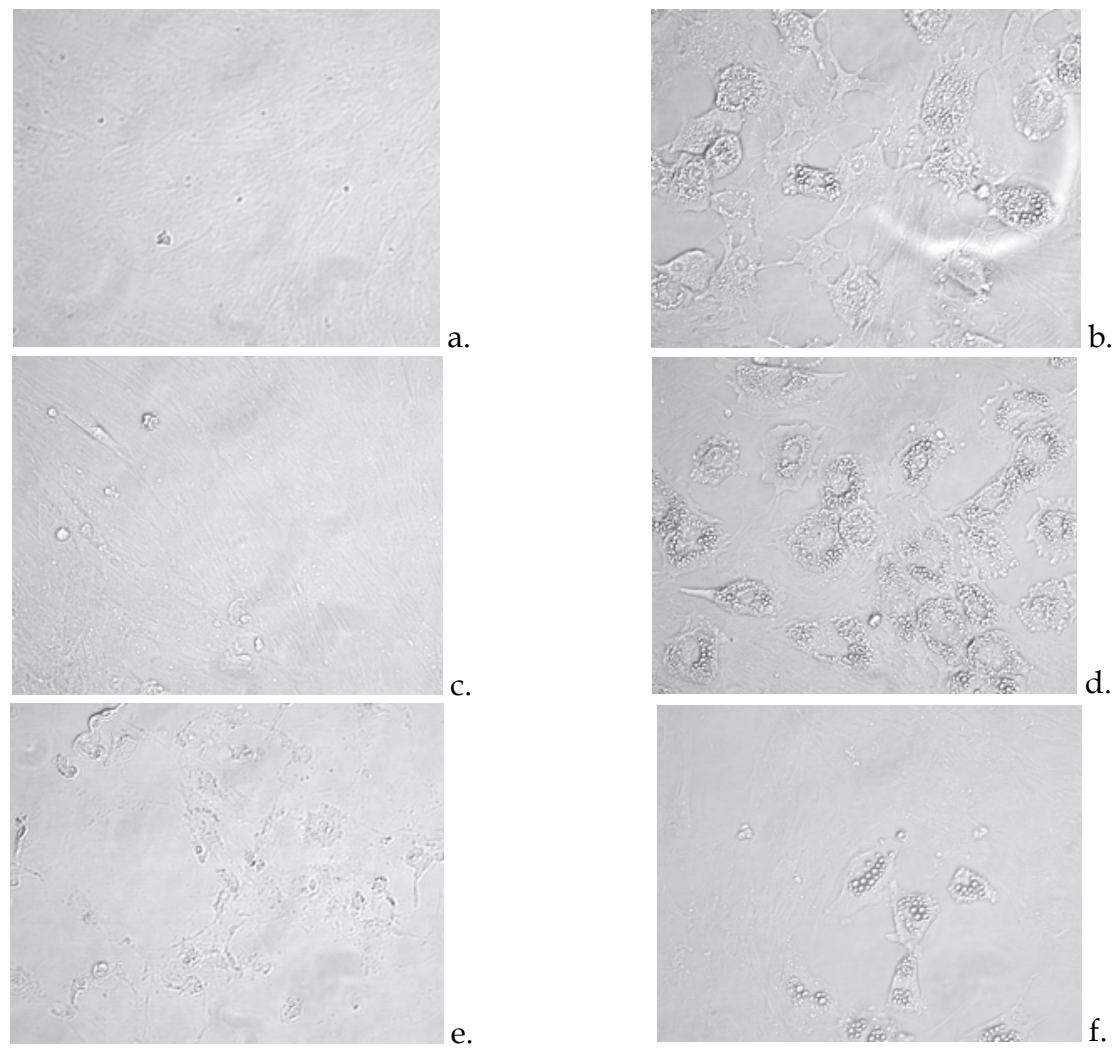

Fig. 4. Spontaneous $(\mathrm{a}, \mathrm{c}, \mathrm{e})$ and induced $(\mathrm{b}, \mathrm{d}, \mathrm{f})$ adipodifferentiation in rat bone marrow MMSCs after 4 days exposure in normoxic $\left(20 \% \mathrm{O}_{2}\right)(\mathrm{a}, \mathrm{b})$, hypoxic $\left(5 \% \mathrm{O}_{2}\right)(\mathrm{c}, \mathrm{d})$ and anoxic $\left(\sim 0 \% \mathrm{O}_{2}\right)(\mathrm{e}, \mathrm{f})$ conditions. Lipid droplets were evaluated with Oil Red O staining, representative images of MMSCs on $3^{\text {rd }}$ passage, $400 x$.

\section{Susceptibility of human adipose-tissue derived MMSCs to anoxia}

In order to expand our understanding of stromal precursor adaptation to extremely low oxygen we continued studies of anoxia effects on human MMSCs from adipose tissue. MMSCs of 2-4 passsages were subjected to anoxic condition over 240 hours. We did not change culture medium in the course of exposure in anoxia, which induced an additional stress from nutrient "starvation". Cells of the same passage were placed in normoxia (20\% $\mathrm{O}_{2}$ ) as reference "starvation" cells, and also reference"standard" cells with regular medium replacement every third day were used.

Cell growth. To characterize cell growth, we evaluated increase in MMSC population in each experimental condition. In the "standard" condition at $20 \% \mathrm{O}_{2}$ MMSC population grew 7.1 folds (Fig. 5). After $240 \mathrm{~h} \mathrm{w} / \mathrm{o}$ medium change, i.e. under nutrients deprivation, growth of normoxic MMSCs made up only 4.4 folds. In anoxic cultures cell population increased 3.9 folds (Fig. 5). Against expectations, anoxia did not suppress MMSCs growth. Increase in 
MMSC number was slightly less pronounced than in normoxic MMSCs in the condition of starvation. It appears, that starvation decreased oxygen demand but did not stop cell proliferation. The mechanism regulating MMSC proliferation under increasing oxygen limitation is still unclear.

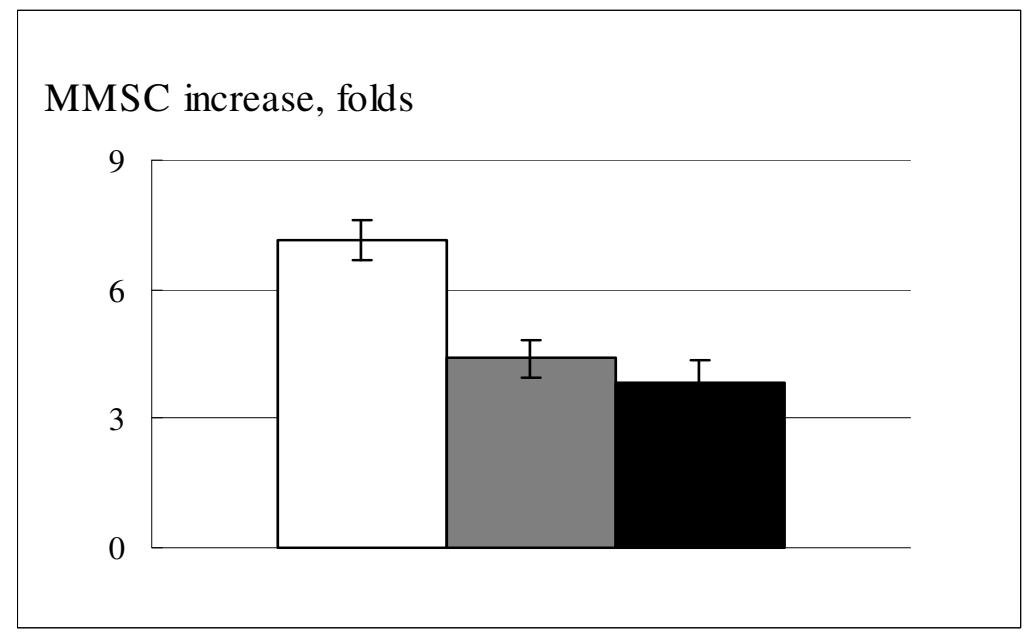

Fig. 5. MMSC increment during expansion in in following conditions: $\square-20 \% \mathrm{O}_{2}$, with regular medium changes (control), $-20 \% \mathrm{O}_{2}$, w/o medium replacement and $\sim 0 \% \mathrm{O}_{2}$, $\mathrm{w} / \mathrm{o}$ medium replacement. Results are representative of three independent experiments. Data are shown as $\mathrm{M}+\mathrm{m}$.

Cell viability. We compared MMSC viability in the experimental conditions described in the context of cell death path (Tabl. 4). After $240 \mathrm{~h}$ in the standard normoxic condition, the share of necrotic and apoptotic MMSCs was similar and fairly low. Growth of MMSCs in normoxia and anoxia w/o medium replacement shifted the ratio of cell death path toward necrotic. Comparison of these data with MMSC proliferation makes it evident that cell population increase is higher in anoxia and that percent of necrotic cells is same as in normoxia, which means MMSCs growth prevails in anoxia.

\begin{tabular}{|c|c|c|c|}
\hline & AnnV+cells (\%) & $P I+$ cells $(\%)$ & $\begin{array}{l}\text { Damaged cells, total } \\
(\%)\end{array}$ \\
\hline \multicolumn{4}{|c|}{ Standard culture condition } \\
\hline $20 \% \mathrm{O}_{2}$ (control) & $2,25 \pm 0,12$ & $2,20 \pm 0,11$ & $4,45 \pm 0,22$ \\
\hline \multicolumn{4}{|c|}{ Growing cells, 240 hrs without medium replacement } \\
\hline $20 \% \mathrm{O}_{2}$ & $0,70 \pm 0,09$ & $9,17 \pm 0,42$ & $9,87 \pm 0,45$ \\
\hline $20 \% \rightarrow 0 \% \mathrm{O}_{2}$ & $2,51 \pm 0,03$ & $9,46 \pm 0,08$ & $11,97 \pm 0,05$ \\
\hline
\end{tabular}

The averaged data of 3 independent experiments are presented as $\mathrm{M} \pm \mathrm{m}$.

Table 3. Human adipose-tissue derived MMSC viability after exposure in normoxia and anoxia. 

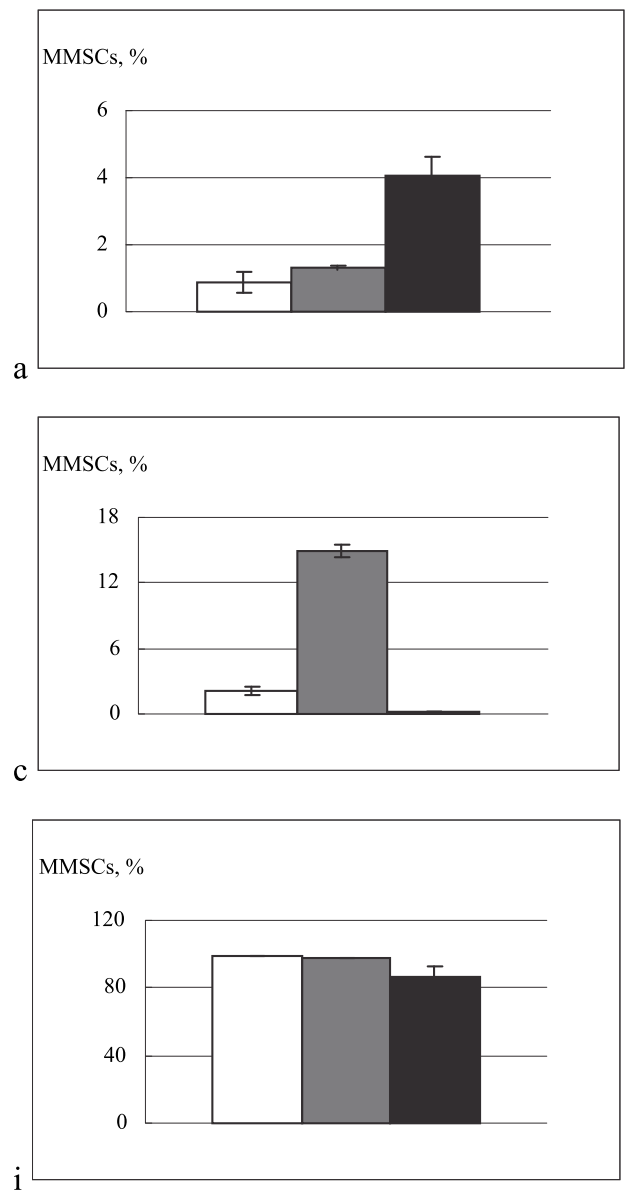
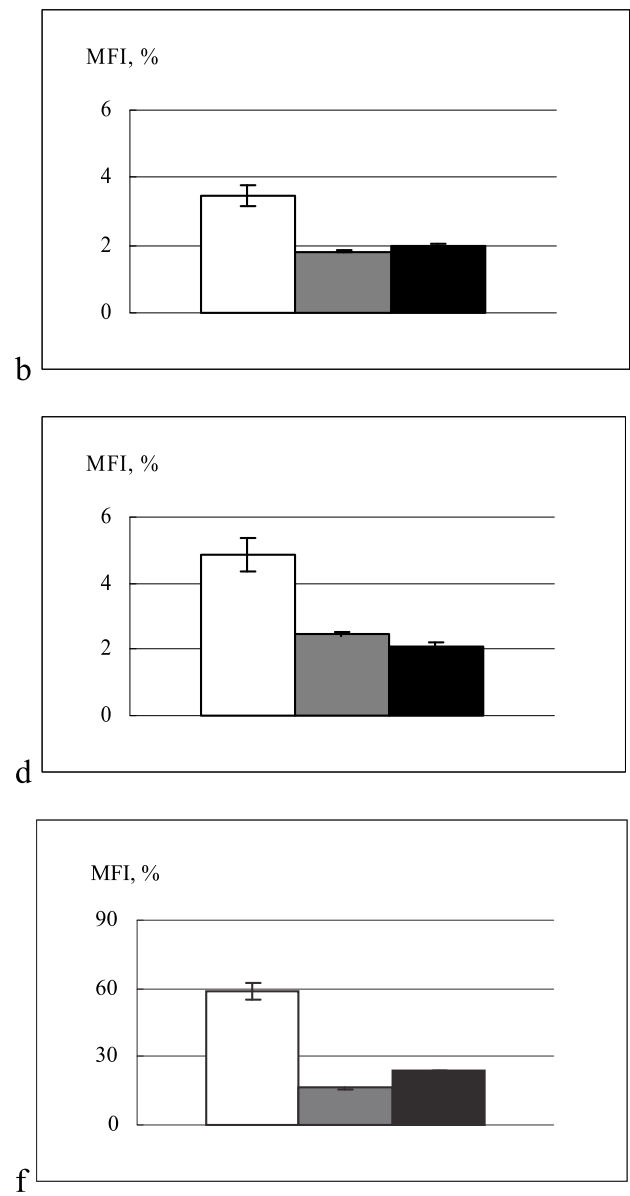

Fig. 6. Cellular metabolism alterations in MMSCs after $240 \mathrm{~h}$ exposure in different culture conditions: $\square-20 \% \mathrm{O}_{2}$, with regular medium changes (control), $\square-20 \% \mathrm{O}_{2}$, w/ o medium replacement and $\sim 0 \% \mathrm{O}_{2}$, w/o medium replacement. a,b. ROS production was evaluated with H2CFDA; c,d. Lyzosomes were stained with LysoTracker Green, f. Mitochondria were stained with MitoTracker Red.a,c,e - Number of stained MMSCs; b,d,f - Mean fluorescence intensity per cell. Results are representative of three independent experiments. Data are shown as $\mathrm{M}+\mathrm{m}$.

Cellular organelle status. To clarify the mechanisms underlining MMSC resistance to extremely low oxygen in microenvironment, we characterized alterations in some vital parameters of cellular homeostasis (Fig. 6). After $240 \mathrm{~h}$ of anoxia, MMSCs demonstrated an increase in percent of MMSCs containing intracellular ROS ( $4 \%$ vs $1.2 \%$ in normoxia) w/o increase in mean fluorescence intensity (MFI) per a cell (the parameter describes the relative amount of fluorochrome in the cell). The number of MMSCs with active lyzosomes and unchanged MFI decreased drastically in anoxia. It is interesting, that long-term anoxia neither affected the mitochondrial compartment (all cells imposed active mitochondria) nor 
influenced the mitochondrial transmembrane potential. Thus, in comparison with normoxia, anoxia increased slightly the number of cells with intracellular ROS and decreased significantly the number of MMSCs with active lyzosomes.

It is nessesary to underline that cell growth potential and viability of human adiposederived MMSCs depend more on nutrient's supply than on the concentration of oxygen. The drastical increase in the number of cells with active lysosomes under combination of nutrients starvation and anoxia should be clarified further.

Taking together, presented data confirm that MMSCs from different source are extraordinary resistant to extermely low oxygen in the microenvironment. In anoxic conditions MMSCs retain their properties to proliferate and differentiate in mesenchymaspecific lineages and also possess fairly high viability. Nevertheless, long-term anoxia provoked cell death in MMSCs mainly through necrotic pathway.

\section{Concluding remarks}

The data reviewed above and our own results demonstrate clearly that low oxygen tension is undoubtedly an important regulator of MMSCs maintenance and plays a pivotal role in architecturing the MMSCs microenvironment. With oxygen partial pressure sublethal or lethal for other cell types, MMSCs not only survive but enhance proliferative activity and slow down differentive capacity supporting "stemness". Low oxygen conditions accentuate the paracrine role of MMSCs by altering the soluble factor release which is also plays an important role in mobilizing MMSCs and recruiting them to site of injury. MMSC ability to outlive low/extremely low oxygen (anoxia) probably, is based on their capacity to upregulate survival pathways and increase glycolytic metabolism. MMSCs are very tolerant of oxygen starvation keeping their morphology, immunophenotype and proliferation rate, demonstrating slightly affected metabolism and potency to mesenchymal lineage differentiation. Short-term anoxia gives start to apoptosis in contrast to hypoxia which exerts the antiapoptotic effects on MMSCs. Long-term anoxia provokes progressive MMSC damage mainly through the necrotic pathway. The effects of hypoxia and anoxia may be diverse and accounted to the fact, that low oxygen simulates the in vivo conditions and can be regarded as an approximation of the physiological MMSC milieu rather than the hypoxic impact. On the contrary, anoxia may represent a real hypoxic microenvironment for these cells.

These results are very encouraging both for understanding particular mechanisms of MMSC existence in different microenvironments and cell therapy as an instrument of MMSC ex vivo modification. In view of the outstanding properties, MMSCs are considered as a perspective tool for cell therapy and regenerative medicine. These cells have already shown a great regenerative potential in preclinical studies and clinical trials. The quality of cell product for these purposes is very important. Up to now, in a few studies MMSCs ex vivo expanded at low oxygen and anoxia demonstrated regenerative properties superior to MMSCs propagated by the standard cultivation. The possibility to modify MMSC properties ex vivo opens great opportunities for implication of "hypoxic" or even "anoxic" protocol for MMSC expansion to meet the needs of cell therapy. Nevertheless, the question about the true hypoxic environment for mesenchymal stromal progenitor cells still has not got the final answer and invites further investigations. 


\section{Acknowledgments}

The work in the authors' laboratories was supported by grants from the Russian Ministry of High Education and Science \#02.522.11.2006, \#11.G34.31.0006 and Program of the Department of Biological Science, Russian Academy of Sciences.

\section{References}

Amellem O, Loffler M, Pettersen EO. Regulation of cell proliferation under extreme and moderate hypoxia: the role of pyrimidine (deoxy) nucleotides. Br J Cancer. 1994;70(5):857-866.

Annabi B, Lee YT, Turcotte S, Naud E, Desrosiers RR, Champagne M, Eliopoulos N, Galipeau J, Béliveau R. Hypoxia promotes murine bone-marrow-derived stromal cell migration and tube formation. Stem Cells. 2003;21(3):337-347.

Anokhina EB, Buravkova LB, Galchuk SV. Resistance of rat bone marrow mesenchymal stromal precursor cells to anoxia in vitro. Bull Exp Biol Med. 2009;148(1):148-151.

Augello A, Kurth TB, De Bari C. Mesenchymal stem cells: a perspective from in vitro cultures to in vivo migration and niches. Eur Cell Mater. 2010;20:121-33.

Betre H, Ong SR, Guilak F, Chilkoti A, Fermor B, Setton LA. Chondrocytic differentiation of human adipose-derived adult stem cells in elastin-like polypeptide. Biomaterials. 2006;27(1):91-99.

Bianco P, Riminucci M, Gronthos S, Robey PG. Bone marrow stromal stem cells: nature, biology, and potential applications. Stem Cells. 2001;19(3):180-192.

Black AC: Human reserve pluripotent mesenchymal stem cells are present in the connective tissues of skeletal muscle and dermis derived from fetal, adult, and geriatric donors. Anat Rec. 2001;264:51-62.

Bosch P, Musgrave DS, Lee JY, Cummins J, Shuler T, Ghivizzani TC, Evans T, Robbins TD, Huard J. Osteoprogenitor cells within skeletal muscle. J Orthop Res. 2000;18:933944.

Bosch P, Pratt SL, Stice SL. Isolation, characterization, gene modification, and nuclear reprogramming of porcine mesenchymal stem cells.Biol Reprod. 2006;74(1):46-57.

Brahimi-Horn MC, Pouysse'gur J. Oxygen, a source of life and stress. FEBS Lett. 2007;581(19):3582-3591.

Braun RD, Lanzen JL, Snyder SA, Dewhirst MW. Comparison of tumor and normal tissue oxygen tension measurements using OxyLite or microelectrodes in rodents. Am. J. Physiol. Heart Circ. Physiol. 2001;280:H2533-H2544.

Bruder SP, Kraus KH, Goldberg VM, Kadiyala S. The effect of implants loaded with autologous mesenchymal stem cells on the healing of canine segmental bone defects. J Bone Joint Surg. 1998;80(7):985-996.

Buravkova LB, Andreeva ER, Zhambalova AP, Romanov YuA. Hematopoiesis induced microenvironment: the role of oxygen and stromal cells. Aerospace and Ecology Medicine. 2010; 44(5):3-8.

Buravkova LB, Anokhina EB. Effect of hypoxia on stromal precursors from rat bone marrow at the early stage of culturing. Bull Exp Biol Med. 2007;143(4):411-413. 
Buravkova LB, Anokhina EB. Mesenchymal stromal progenitor cells: general characteristics and functional state in low oxygen tension. Russian Physiol J. 2008;94(7):737-57.

Buravkova LB, Grinakovskaia OS, Andreeva EP, Zhambalova AP, Kozionova MP. Characteristics of human lipoaspirate-isolated mesenchymal stromal cells cultivated under a lower oxygen tension. Cell Tiss Biol. 2009;3(1):23-28.

Caballero M, Reed CR, Madan G, van Aalst JA. Osteoinduction in umbilical cord- and palate periosteum-derived mesenchymal stem cells. Ann Plast Surg. 2010;64(5):605-609.

Calvi LM, Adams GB, Weibrecht KW, Weber JM, Olson DP, Knight MC, Martin RP, Schipani E, Divieti P, Bringhurst FR, Milner LA, Kronenberg HM, Scadden DT. Osteoblastic cells regulate the haematopoietic stem cell niche. Nature. 2003;425(6960):841-846.

Caplan AI. Adult mesenchymal stem cells for tissue engineering versus regenerative medicine. J Cell Physiol. 2007;213(2):341-347.

Csete M. Oxygen in the cultivation of stem cells. Ann N Y Acad Sci. 2005;1049:1-8.

Cipolleschi MG, Dellosbarba P, Olivotto M. The role of hypoxia in the maintenance of hematopoietic stem-cells. Blood.1993;82(7):2031-2037.

Das R, Jahr H, van Osch GJ, Farrell E. The role of hypoxia in bone marrow-derived mesenchymal stem cells: considerations for regenerative medicine approaches. Tissue Eng Part B Rev. 2010;16(2):159-168.

D'Ippolito G, Diabira S, Howard GA, Menei P, Roos BA, Schiller PC. Marrow-isolated adult multilineage inducible (MIAMI) cells, a unique population of postnatal young and old human cells with extensive expansion and differentiation potential. J Cell Sci. 2004;117(Pt 14):2971-2981.

Eliasson P, Jönsson JI. The hematopoietic stem cell niche: low in oxygen but a nice place to be. J Cell Physiol. 2010;222(1):17-22.

Erecinska, M., and Silver, I.A. (2001). Tissue oxygen tension and brain sensitivity to hypoxia. Respir. Physiol. 128, 263-276.

Fehrer C, Brunauer R, Laschober G, Unterluggauer H, Reitinger S, Kloss F, Gully C, Gassner R, Lepperdinger G. Reduced oxygen tension attenuates differentiation capacity of human mesenchymal stem cells and prolongs their lifespan. Aging Cell. 2007;6(6):745-757.

Friedenstein AJ, Gorskaja JF, Kulagina NN. Fibroblast precursors in normal and irradiated mouse hematopoietic organs. Exp. Hematol. 1976;4(5):267-274.

Gardner LB, Li Q, Park MS, Flanagan WM, Semenza GL, Dang CV. Hypoxia inhibits G1/S transition through regulation of p27 expression. J Biol Chem. 2001;276(11):791926.

Gimble JM, Katz AJ, Bunnell BA. Adipose-Derived Stem Cells for Regenerative Medicine. Circ Res. 2007;100(9):1249-1260.

Goda N, Ryan HE, Khadivi B, McNulty W, Rickert RC, Johnson RS. Hypoxia-inducible factor 1alpha is essential for cell cycle arrest during hypoxia. Mol Cell Biol. 2003;23(1):359-69. 
Grayson WL, Zhao F, Izadpanah R, Bunnell B, Ma T. Effects of hypoxia on human mesenchymal stem cell expansion and plasticity in 3D constructs. J Cell Physiol. 2006;207(2):331-339.

Greijer AE, van der Wall E. The role of hypoxia inducible factor 1 (HIF-1) in hypoxia induced apoptosis. J Clin Pathol. 2004;57(10):1009-14

Grinakovskaya OS, Andreeva ER, Buravkova LB, Rylova YV, Kosovsky GY. Low level of O2 inhibits commitment of cultured mesenchymal stromal precursor cells from the adipose tissue in response to osteogenic stimuli. Bull Exp Biol Med. 2009;147(6):760763

He A, Y Jiang, C Gui, Y Sun, J Li, J Wang. The antiapoptotic effect of mesenchymal stem cell transplantation on ischemic myocardium is enhanced by anoxic preconditioning. Can J Cardiol 2009;25(6):353-358.

Hu X, Yu SP, Fraser JL, Lu Z, Ogle ME, Wang JA, Wei L. Transplantation of hypoxiapreconditioned mesenchymal stem cells improves infarcted heart function via enhanced survival of implanted cells and angiogenesis. J Thorac Cardiovasc Surg. 2008;135(4):799-808.

Ivanovic Z. Hypoxia or in situ normoxia: The stem cell paradigm. J Cell Physiol. 2009;219(2):271-275.

Izadpanah R, Trygg C, Patel B, Kriedt C, Dufour J, Gimble JM, Bunnell BA. Biologic properties of mesenchymal stem cells derived from bone marrow and adipose tissue. J. Cell. Biochem. 2006;99(5):1285-1297.

Jiang BH, Semenza GL, Bauer C, Marti HH. Hypoxia-inducible factor 1 levels vary exponentially over a physiologically relevant range of $\mathrm{O}_{2}$ tension. Am J Physiol. 1996;271(4 Pt 1):C1172-80.

Jones DL, Wagers AJ. No place like home: anatomy and function of the stem cell niche. Nat Rev Mol Cell Biol. 2008;9(1):11-21.

Khan WS, Adesida AB, Hardingham TE. Hypoxic conditions increase hypoxia-inducible transcription factor 2alpha and enhance chondrogenesis in stem cells from the infrapatellar fat pad of osteoarthritis patients. Arthritis Res Ther 2007;9(3):R55.

Kolf CM, Cho E, Tuan RS. Biology of adult mesenchymal stem cells: regulation of niche, self-renewal and differentiation. Arthritis Res. 2007;9(1):204.

Kurose R, Ichinohe S, Tajima G, Horiuchi S, Kurose A, Sawai T, Shimamura T. Characterization of human synovial fluid cells of 26 patients with osteoarthritis knee for cartilage repair therapy. Int J Rheum Dis. 2010;13(1):68-74.

Lee EY, Xia Y, Kim WS, Kim MH, Kim TH, Kim KJ, Park BS, Sung JH. Hypoxia-enhanced wound-healing function of adipose-derived stem cells: increase in stem cell proliferation and up-regulation of VEGF and bFGF. Wound Repair Regen. 2009;17(4):540-7

Lee JH, Kemp DM. Human adipose-derived stem cells display myogenic potential and perturbed function in hypoxic conditions. Biochem Biophys Res Commun. 2006;341(3):882-888.

Lee RH, Kim B, ChoiI, Kim H, Choi HS, Suh K, Bae YC, Jung JS. Characterization and expression analysis of mesenchymal stem cells from human bone marrow and adipose tissue. Cell Physiol Biochem. 2004;14(4-6):311-324. 
Leist M, Single B, Castoldi AF, Kuhnle S, Nicotera P. Intracellular adenosine triphosphate (ATP) concentration: a switch in the decision between apoptosis and necrosis. J Exp Med. 1997; 185(8):1481-6.

Lennon DP, Edmison JM, Caplan AI. Cultivation of rat marrow-derived mesenchymal stem cells in reduced oxygen tension: effects on in vitro and in vivo osteochondrogenesis. J Cell Physiol. 2001;187(3):345-355.

Li L, Xie T. Stem cell niche: structure and function. Annu. Rev.Cell Dev. Biol. 2005;21, 605631.

Lozito TP, Kolf CM,Tuan RM. Microenvironmental regulation of adult mesenchymal stem cells. In: V.K. Rajasekhar, M.C. Vemuri (eds.), Regulatory Networks in Stem Cells, Stem Cell Biology and Regenerative Medicine, Humana Press, 2009:185210.

Ma T, Grayson WL, Frohlich M, Vunjak-Novakovic G. Hypoxia and stem cell-based engineering of mesenchymal tissues. Biotechnol Prog. 2009;25(1):32-42.

Madonna R, Geng YJ, De Caterina R. Adipose tissue-derived stem cells characterization and potential for cardiovascular repair. Arterioscler Thromb Vasc Biol. 2009;29(11):1723-1729.

Majumdar MK, Banks V, Peluso DP, Morris EA. Isolation, characterization, and chondrogenic potential of human bone marrow-derived multipotential stromal cells. J. Cell Physiol. 2000;185(1):98-106.

Makino S, Fukuda K, Miyoshi S, Konishi F, Kodama H, Pan J, Sano M, Takahashi T, Hori $\mathrm{S}$, Abe H, Hata J, Umezawa A, Ogawa S. Cardiomyocytes can be generated from marrow stromal cells in vitro. J. Clin. Invest. 1999;103(5):697-705.

Malda J, Klein TJ, Upton Z. The roles of hypoxia in the in vitro engineering of tissues. Tissue Eng. 2007;13(9):2153-2156.

Matsuda N, Morita N, Matsuda K, Watanabe M. Proliferation and differentiation of human osteoblastic cells associated with differential activation of MAP kinases in response to epidermal growth factor, hypoxia, and mechanical stress in vitro. Biochem Biophys Res Commun. 1998;249(2):350-4.

Mohyeldin A, Garzo'n-Muvdi T, Quin ones-Hinojosa A. Oxygen in stem cell biology: a critical component of the stem cell niche. Cell Stem Cell. 2010; 7(2):150-61.

Panchision DM. The role of oxygen in regulating neural stem cells in development and disease. J Cell Physiol. 2009;220:562-568.

Parmar K, Mauch P, Vergilio JA, Sackstein R, Down JD. Distribution of hematopoietic stem cells in the bone marrow according to regional hypoxia. Proc Natl Acad Sci USA. 2007;104(13):5431-5436.

Pittenger MF, Mackay AM, Beck SC, Beck SC, Jaiswal RK, Douglas R, Mosca JD, Moorman MA, Simonetti DW, Craig S, Marshak DR. Multilineage potential of adult human mesenchymal stem cells. Science. 1999;284(5411):143-147.

Rehman J, Traktuev D, Li J, Merfeld-Clauss S, Temm-Grove CJ, Bovenkerk JE, Pell CL, Johnstone $\mathrm{BH}$, Considine RV, March KL. Secretion of angiogenic and antiapoptotic factors by human adipose stromal cells. Circulation. 2004; 109 (10): 1292-1298. 
Ren H, Cao Y, Zhao Q, Li J, Zhou C, Liao L, Jia M, Zhao Q, Cai H, Han ZC, Yang R, Chen G, Zhao RC. Proliferation and differentiation of bone marrow stromal cells under hypoxic conditions. Biochem Biophys Res Commun. 2006;347(1):12-21.

Romanov YA, Darevskaya AN, Kabaeva NV, Antonova OA. Optimum conditions for culturing of human bone marrow and adipose tissue mesenchymal precursor cells. Bull Exp Biol Med. 2006;142(4):515-20.

Rosová I, Dao M, Capoccia B, Link D, Nolta JA. Hypoxic preconditioning results in increased motility and improved therapeutic potential of human mesenchymal stem cells. Stem Cells. 2008;26(8):2173-2182.

Salim A, Nacamuli RP, Morgan EF, Giaccia AJ, Longaker MT. Transient changes in oxygen tension inhibit osteogenic differentiation and Runx2 expression in osteoblasts. J Biol Chem. 2004;279(38):40007-40016.

Scadden DT. The stem-cell niche as an entity of action. Nature 2006;441:1075-1079.

Schäffler A, Büchler C. Concise review: adipose tissue-derived stromal cells--basic and clinical implications for novel cell-based therapies. Stem Cells. 2007;25(4):818827.

Schmaltz C, Hardenbergh PH, Wells A, Fisher DE. Regulation of proliferation-survival decisions during tumor cell hypoxia. Mol Cell Biol. 1998;18(5):2845-54.

Schofield R. The relationship between the spleen colony-forming cell and the haemopoietic stem cell. Blood Cells. 1978; 4:7-25.

Shake JG, Gruber PJ, Baumgartner WA, Senechal G, Meyers J, Redmond JM, Pittenger MF, Martin BJ. Mesenchymal stem cell implantation in a swine myocardial infarct model: Engraftment and functional effects. Ann Thorac Surg. 2002;73(6):19191925.

Shi S, Grontos S. Perivascular niche of postnatal mesenchymal stem cells in human bone marrow and dental pulp. J Bone Miner Res. 2003;18(4):696-704.

Silvan U, Diez-Torre A, Arluzea J, Andrade R, Silio M, Arechaga J. Hypoxia and pluripotency in embryonic and embryonal carcinoma stem cell biology. Differentiation 2009;78:159-168.

Suzuki H, Tomida A, Tsuruo T. Dephosphorylated hypoxia-inducible factor 1alpha as a mediator of p53-dependent apoptosis during hypoxia. Oncogene. 2001;20(41):5779-88.

Tuncay OC, Barker MK Oxygen tension regulates osteoblast function. Am J Orthod Dentofacial Orthop. 1994; 105(5): 457 - 463.

Valtieri M, Sorrentino A. The mesenchymal stromal cell contribution to homeostasis. J. Cell Physiol. 2008;217(2):296-300.

Villarruel SM, Boehm CA, Pennington M, Bryan JA, Powell KA, Muschler GF. The effect of oxygen tension on the in vitro assay of human osteoblastic connective tissue progenitor cells. J Orthop Res. 2008;26(10):1390-7.

Vlaski M, Lafarge X, Chevaleyre J, Duchez P, Boiron JM, Ivanovic Z. Low oxygen concentration as a general physiologic regulator of erythropoiesis beyond the EPO-related downstream tuning and a tool for the optimization of red blood cell production ex vivo. Exp Hematol. 2009;37(5):573-584. 
Wagner W, Wein F, Seckinger A, Frankhauser M, Wirkner U, Krause U, Blake J, Schwager C, Eckstein V, Ansorge W, Ho AD. Comparative characteristics of mesenchymal stem cells from human bone marrow, adipose tissue, and umbilical cord blood. Exp Hematol. 2005;33(11):1402-1416.

Wang DW, Fermor B, Gimble JM, Awad HA, Guilak F. Influence of oxygen on the proliferation and metabolism of adipose derived adult stem cells. J Cell Physiol. 2005;204(1):184-191.

Yin, T., and Li, L. (2006). The stem cell niches in bone. J. Clin. Invest. 116, 1195-1201.

Zhambalova AP, Darevskaya AN, Kabaeva NV, Romanov YA, Buravkova LB. Specific interaction of cultured human mesenchymal and hematopoietic stem cells under conditions of reduced oxygen content. Bull Exp Biol Med. 2009;147(4):525-30.

Zuk PA, Zhu M, Ashjian P, De Ugarte DA, Huang JI, Mizuno H, Alfonso ZC, Fraser JK, Benhaim P, Hedrick MH. Human adipose tissue is a source of multipotent stem cell. Mol Biol Cell. 2002;13(12):4279-4295.

Zuk PA, Zhu M, Mizuno H, Huang J, Futrell JW, Katz AJ, Benhaim P, Lorenz HP, Hedrick MH. Multilineage cells from human adipose tissue: implications for cell-based therapies. Tissue Eng. 2001;7(2):211-228.

Zvaifler NJ, Marinova-Mutafchieva L, Adams G, Edwards CJ, Moss J, Burger JA, Maini $\mathrm{RN}$ : Mesenchymal precursor cells in the blood of normal individuals. Arthritis Res. 2000; 2:477-488. 


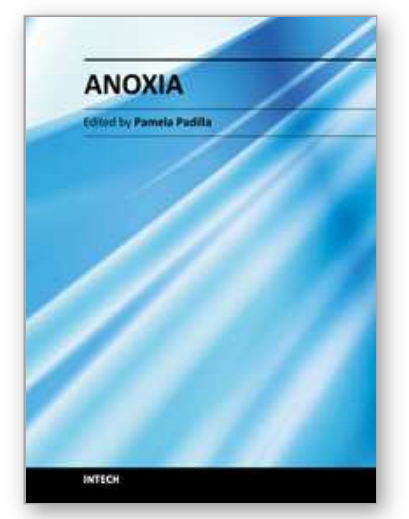

\author{
Anoxia \\ Edited by Dr. Pamela Padilla
}

ISBN 978-953-307-664-5

Hard cover, 146 pages

Publisher InTech

Published online 05, January, 2012

Published in print edition January, 2012

This book reviews how severe oxygen deprivation affects biological systems - from the molecular to the ecological level. The contributing authors come from diverse regions of the world, which proves the interest in the academic analysis of oxygen deprivation. The diversity in the experimental approach scientists take, in order to understand the influence oxygen deprivation has on living systems, is apparent throughout this book. One of the presented ideas deals with the exploration and examination of the physiological, cellular and genetic characteristics of killifish embryos and nematodes exposed to anoxia. Furthermore, the book includes material on the mechanisms regulating hypoxia and anoxia tolerance and their implications of on human health issues. Finally, new methodologies to examine oxygen deprivation and the impact of human-related activities on oxygen level, within important ecological systems such as Lake Victoria, are presented. There is no doubt that the oxygen molecule is central to every stratum of biological systems.

\title{
How to reference
}

In order to correctly reference this scholarly work, feel free to copy and paste the following:

L.B. Buravkova, E.R. Andreeva, J.V. Rylova and A.I. Grigoriev (2012). Resistance of Multipotent Mesenchymal Stromal Cells to Anoxia In Vitro, Anoxia, Dr. Pamela Padilla (Ed.), ISBN: 978-953-307-664-5, InTech, Available from: http://www.intechopen.com/books/anoxia/resistance-of-multipotent-mesenchymal-stromal-cells-toanoxia-in-vitro

\section{INTECH}

open science | open minds

\section{InTech Europe}

University Campus STeP Ri

Slavka Krautzeka 83/A

51000 Rijeka, Croatia

Phone: +385 (51) 770447

Fax: +385 (51) 686166

www.intechopen.com

\section{InTech China}

Unit 405, Office Block, Hotel Equatorial Shanghai

No.65, Yan An Road (West), Shanghai, 200040, China 中国上海市延安西路65号上海国际贵都大饭店办公楼 405 单元 Phone: +86-21-62489820

Fax: $+86-21-62489821$ 
(C) 2012 The Author(s). Licensee IntechOpen. This is an open access article distributed under the terms of the Creative Commons Attribution 3.0 License, which permits unrestricted use, distribution, and reproduction in any medium, provided the original work is properly cited. 